JUNO: A STLdy IN EARLY ROMAN Religion. By Emily Ledyard Shields. Smith College Classical Studies, No. 7. Northampton, Mass., Collegiate Press, Menasha, Wis., 1926. Pp. 74.

A review of the theories invented by etymologists and students of ancient religion concerning Juno, 'with a view to a possible return to the former idea that the origin of Juno-worship is related to Jupiter and that she was first a goddess of light.' Nothing could be more painstaking than the way in which the history, not so much of the subject itself, as of the attitude of various scholars towards it, is traced; every expression of opinion, regardless of the weight of authority behind it, is solemnly recorded. As an index to other people's contributions to the problem the little book is useful; we hope the writer will follow it up with a more independent study.

VELLEIUS PATERCLLCS AND RES GESTAF, DIVI AUGUSTI : With an English translation. By Frederick W. Shiplex. The Loeb Classical Libraty, 1924. Pp. xx +432 . ros.

The text of Velleius is based on Halm and Ellis with the addition of many conjectures from older editors. Professor Shipley has added a short introduction on the characteristics of his author. The translation is gencrally adequate, but there appear to be slips in one or two places (v. P. 94, 1.21 ; I43, I3, with 145,8; 146, 22 reus = accused ?; I96, I6). On p. I98, 1 . I 3 certebat is a misprint for certabat.

The text of the Res Gestae is based on Diehl. The editor gives the necessary historical commentary, sometimes a little inadequately (v. p. 399, note b).

The whole work has a full index.

A. C.

DIE DisticheN DES CATUll. Von Otto Weinreich. Tübingen: J. C. B. Mohr, 1926. Pp. I10.

Seven couplets of Catullus form the theme of this book-a short book, it is true, but, even so, is this not an offence against that brevity which is the soul of the distich itself ? The work of Catullus is carefully considered in the light of earlier writers of epigram and is freely illustrated by modern parallels. There are many detailed observations that show insight and wisdom, and the meaning of the various couplets is very carefully brought out: but, frankly, if there is no more in several of them than appears, they are hardly worth more than a passing thought. And when we come to the great 'Odi et amo...' can we add much to its immediate appeal?

H. M.

\title{
EDITORIAI NOTF,
}

Mr. Edward Foord draws our attention to the fact that in a review of his work "The Last Age of Roman Britain' which appeared in J.R.S. xv, p. II4, it is stated that the book 'is written to sustain the thesis which Professor Bury broached two or three years ago, to the effect that the subjection of the province of Britain to the central imperial organisation did not end in $4 \mathrm{I}$, according to the theory generally received, but continued for a long generation after.' Mr. Foord, in the Preface to his book (p. 5), makes it clear that his study of the subject began in 1910 ; and we greatly regret that a phrase used in our notice of the book should have conveyed the impression (which, as we are assured by the reviewer, was not intended) that Mr. Foord's primary object in writing the work was to furnish support to a thesis advanced by another scholar. Mr. Foord's view on the single point of the date of the evacuation no doubt approximates to that of Professor Bury, but was formed by him as the result of independent research, and we would add that the main portion of his book deals with other problems of the obscure and difficult period between 337 and 582 . 